\title{
Spotkanie po ASCO 2013
}

U progu letnich wakacji, w dniach 28-29 czerwca $2013 \mathrm{r}$. w Gdańsku po raz dwunasty odbyło się „Spotkanie po ASCO”. Tradycyjnie podsumowano na nim najważniejsze doniesienia Kongresu Amerykańskiego Towarzystwa Onkologii Klinicznej (ASCO), który odbył się niespełna miesiąc wcześniej w Chicago. Nowością tegorocznego „Spotkania..." były zmiany w gronie wykładowców. Prowadzący Konferencję od pierwszej edycji i najaktywniejsi wykładowcy — Jacek Jassem i Maciej Krzakowski — postanowili pozostać obecnie jedynie komentatorami wykładów i „duchowymi opiekunami". Omawiane przez nich w uprzednich latach tematy zaprezentowali w tym roku Rafał Dziadziuszko (rak płuca) i Aleksandra Łacko (rak piersi). Tych ostatnich zastąpili z kolei dwaj nowi wykładowcy - Radosław Mądry, który omówił nowotwory narządu rodnego, oraz Piotr Wysocki, który przedstawił badania nad nowymi lekami. Ogólna formuła spotkania nie uległa zmianie, a roszady w gronie wykładowców zostały ciepło przyjęte przez uczestników Konferencji. Komentarze Jacka Jassema i Macieja Krzakowskiego mają również ogromne znaczenie dydaktyczne, zwykle bowiem odnoszą wyniki badań do codziennej praktyki oraz uwarunkowań organizacyjnych, prawnych i finansowych obowiązujących w naszym kraju.

\section{Biologia nowotworów i nowe leki}

Piotr Wysocki

Wykład zdominowały doniesienia dotyczące immunologii nowotworów. W badaniach nad nowymi lekami obserwuje się wielki powrót do immunoterapii. Mimo że w większości są to badania wczesnych faz, panuje opinia, że po latach niepowodzeń w badaniach nad zastosowaniem szczepionek najbliższe lata należeć będą do leków immunologicznych. Staje się to możliwe dzięki rozwojowi nauk podstawowych i lepszemu poznaniu mechanizmów nadzoru immunologicznego oraz sposobów wymykania się komórek nowotworowych spod tego nadzoru. Przedstawiono kilka badań na lekami ukierunkowanymi na receptor PD-1 (białko zaprogramowanej śmierci komórki - programmed cell death protein 1) i jednego z jego ligandów immunosupresyjnych — PD-L1. PD-1 to receptor supresyjny, obecny na powierzchni aktywowanych limfocytów T.
Ukierunkowane na niego przeciwciało monoklonalne - niwolumab - jest nowym, obiecującym i dobrze tolerowanym lekiem (abstr. 3002 - różne nowotwory lite, 9011 i 9012 - zaawansowany czerniak), podobnie jak przeciwciało skierowane na ligand dla PD-1 (abstr. 9010). Badania nad immunoterapią dotyczą nie tylko nowych leków. Niektóre znane leki molekularnie ukierunkowane są też obiecującymi modulatorami odpowiedzi immunologicznej. Trastuzumab indukuje mechanizmy humoralne swoiste dla antygenu HER2 i u części chorych indukuje powstawanie przeciwciał anty-HER2 niebędących trastuzumabem. Są to własne przeciwciała chorego, które powstają w wyniku aktywacji układu odpornościowego. Wykazano, że występowanie przeciwciał własnych wiąże się z lepszym rokowaniem (abstr. 521 — leczenie trastuzumabem zaawansowanego raka piersi i abstr. 522 - leczenie uzupełniające). Cetuksymab, zawierający zmodyfikowane reszty cukrowe, zachowuje aktywność przeciwciała anty-EGFR oraz dobry profil bezpieczeństwa, a jednocześnie wykazuje zwiększoną aktywność mechanizmów cytotoksyczności komórkowej, zależnej od przeciwciał (antibody dependent cellular cytotoxicity - ADCC, abstr. 3008).

\section{Epidemiologia i profilaktyka}

Renata Duchnowska

Podczas sesji plenarnej Kongresu ASCO przedstawiane są badania uznane przez komitet naukowy za najważniejsze spośród wielu tysięcy zgłoszonych prac. Rzadko znajdują się tam doniesienia dotyczące epidemiologii i profilaktyki. W tym roku przedstawiono jednak w tej sesji indyjskie badanie kliniczne z randomizacją, w którym potwierdzono skuteczność prostych badań przesiewowych w kierunku raka szyjki macicy. Zastosowano w nim metodę wizualnej oceny zmian w obrębie szyki macicy po wybarwieniu jej roztworem kwasu octowego (abstr. 2). Rak szyjki macicy to choroba krajów ubogich, zachorowania w Indiach to ok. 30\% wszystkich zachorowań na świecie, a śmiertelność jest bardzo wysoka. Do badania włączono ponad 150 tys. kobiet w wieku 35-64 lat, a testy były prowadzone przez odpowiednio przeszkolony (4-tygodniowy kurs) personel niemedyczny. Stwierdzono 31-procentowe zmniejszenie umieralności 
z powodu raka szyjki macicy w grupie poddanej badaniom przesiewowym w porównaniu z grupą kontrolną $(R R=0,69$; $\mathrm{p}=0,003)$. Podkreślono, że badanie zostało bardzo dobrze zaplanowane, a przyjęta hipoteza znajduje potwierdzenie w rzeczywistej populacji. Badanie ma również duży wydźwięk etyczny i ogólnoludzki. W dobie nowoczesnej i bardzo kosztownej opieki zdrowotnej w krajach rozwiniętych pokazało ono, jak wiele można uzyskać właściwą profilaktyką, szczególnie w populacji, w której leczenie (jakiekolwiek) jest dostępne dla nielicznych.

Profilaktyczna amputacja piersi u zdrowych nosicielek mutacji BRCA1/2 to gorący temat medialny ostatnich mięsięcy. Obecnie najbardziej popularną metodą jest zabieg z zaoszczędzeniem brodawki sutkowej. W retrospektywnej analizie wykazano, że resztkowa tkanka włóknisto-gruczołowa pozostawiona po takim zabiegu nie zwiększa istotnie ryzyka wystąpienia raka piersi (abstr. 1507). Alternatywą dla profilaktycznych amputacji w grupie kobiet o wysokim ryzyku zachorowania może się okazać stosowanie badań przesiewowych metodą rezonansu magnetycznego (abstr. 1506). Kobiety z mutacją, które zachorowały na raka jednej piersi, mają 20-60\% ryzyko zachorowania na raka drugiej piersi. W badaniu holenderskim wykazano, że u chorych nosicielek, u których w ciągu 2 lat po pierwotnym leczeniu nie zaobserwowano nawrotu choroby, profilaktyczna amputacja drugiej piersi pozwala na znamienne obniżenie ryzyka kolejnego zachorowania, a także na poprawę wskaźników przeżycia (10-letnie przeżycia całkowite 90\% w grupie poddanej profilaktycznej amputacji w porównaniu z 80\% w grupie kontrolnej, $p=0,008$; abstr. 1502). Natomiast obustronne usunięcie przydatków u chorych na raka piersi bez mutacji $B R C A 1 / 2$ nie zmniejsza ryzyka wystąpienia raka drugiej piersi (abstr. 1511). Systematycznie pojawiają się badania dotyczące związku palenia tytoniu z zachorowaniem na raka płuca. Po raz kolejny potwierdzono, że palenie tytoniu zwiększa ryzyko zachorowania, szczególnie w odniesieniu do raka drobnokomórkowego (100\%) i płaskonabłonkowego (niemal 90\%, abstr. 1504). Powoduje ono również zwiększenie ryzyka zachorowania na raka płuca i zgonu u kobiet po menopauzie, stosujących hormonalną terapię zastępczą (abstr. 1524).

\section{Chłoniaki}

Renata Zaucha

Na tegorocznym Kongresie ASCO przedstawiono dużo badań I i Il fazy dotyczących leczenia chłoniaków nowymi molekularnie ukierunkowanymi lekami. Ważnym celem molekularnym jest receptor komórki B (B-cell receptor - BCR), którego ekspresję stwierdza się we wszystkich chłoniakach B-komórkowych. Jest to kluczowy element szlaku sygnałowego dla procesów proliferancji, migracji i przeżycia limfo- cytów $B$, w którym uczestniczy m.in. kinaza fosfatydyloinozytolu (PI3K). Idelalizyb, doustny inhibitor kinazy PI3K, hamuje proliferację, indukuje apoptozę w komórkach nowotworów z limfocytow B oraz skraca czas życia tych komórek. W badaniach I fazy, zastosowany w skojarzeniu z rituksymabem i bendamustyną, okazał się aktywny i względnie dobrze tolerowany w leczeniu chorych z opornymi nawrotami chłoniaków grudkowych (abstr. 8500) i chłoniaków z komórek płaszcza (abstr. 8501). Połączenie idelalizybu z ewerolimusem lub bortezomibem wiązało się natomiast ze znaczną toksycznością (biegunki, posocznice, zapalenia płuc, zgony, abstr. 8501). Wartość idelalizybu wymaga potwierdzenia w badaniach kolejnych faz. Dotyczy to także wielu innych nowych leków, m.in. ibrutinibu - doustnego inhibitora kinazy tyrozynowej Brutona (abstr. 8502) czy mogamulizumabu - humanizowanego przeciwciała monoklonalnego przeciwko receptorowi CCR4 limfocytów T (abstr. 8506). Konieczne jest również przeprowadzenie badań, które pozwolą ustalić optymalne miejsce dla nowych terapii. Obecnie nie znamy odpowiedzi na wiele pytań, m.in. w której linii leczenia stosować nowe leki, czy w skojarzeniu z chemioterapią, w leczeniu podtrzymujacym, w kondycjonowaniu?

Chorzy po zakończonym leczeniu onkologicznym podlegają systematycznej kontroli, której celem jest m.in. wczesne wykrycie nawrotu choroby. Jednym z elementów tej obserwacji jest cykliczne wykonywanie badań obrazowych, co w odniesieniu do wybranych nowotworów (m.in. chłoniaka Hodgkina i chłoniaka rozlanego z dużych komórek B, DLBCL) stało się standardem postępowania. Rzeczywista wartość takiego postępowania pozostaje jednak przedmiotem kontrowersji. Nie ma bowiem wyników badań potwierdzających jednoznacznie ich korzyść kliniczną, a równocześnie są one związane ze szkodliwą ekpozycją na promieniowanie X, fałszywie dodatnimi wynikami i wysokimi kosztami. W wieloośrodkowej analizie kohortowej wykazano, że nawroty po leczeniu DLBCL wykryto za pomocą badań obrazowych tylko u 1,5\% chorych (abstr. 8504). W pozostałych przypadkach rozpoznanie nawrotu poprzedzały objawy kliniczne, odchylenia w badaniu fizykalnym czy w badaniach laboratoryjnych (np. wzrost stężenia dehydrogenazy mleczanowej, LDH). Podobne wyniki uzyskano, analizując wartość badań obrazowych u chorych po zakończeniu leczenia z powodu chłoniaka Hodgkina (abstr. 8505).

\section{Nowotwory głowy i szyi}

Monika Rucińska

Skojarzone leczenie miejscowo zaawansowanych raków obszaru głowy i szyi jest od lat przedmiotem kontrowersji. Chemioterapia zastosowana jednoczasowo z radioterapią poprawia wskaźniki przeżycia w porównaniu z wyłączną radioterapią. Chemioterapia zastosowana indukcyjnie, 
mimo wysokiego odsetka odpowiedzi i zmniejszenia ryzyka przerzutów odległych, pozostaje bez wpływu na całkowite przeżycie, co po raz kolejny potwierdzono w badaniu z losowym doborem chorych (abstr. 6003). W tym samym badaniu porównano również chemioterapię (5-fluorouracyl z cisplatyną) i cetuksymab w skojarzeniu z radioterapią. Rola cetuksymabu w leczeniu zaawansowanych raków obszaru głowy i szyi jest znana od kilku lat; jego dołączenie do radykalnej radioterapii lub paliatywnej chemioterapii wpływa na poprawę wyników leczenia. Porównany z chemioterapią jako element leczenia skojarzonego z napromienianiem wykazał podobną skuteczność (porównywalne odsetki odpowiedzi i parametry czasu przeżycia wolnego od choroby i całkowitego) i toksyczność. Leczenie z cetuksymabem powodowało jednak znacznie więcej przerw w leczeniu, co skutkowało niekorzystnym wydłużeniem czasu leczenia. Wydaje się zatem, że obecnie cetuksymab w skojarzeniu z radioterapią może być zastosowany u tych nielicznych chorych, którzy nie mogą otrzymać chemioterapii (np. z powodu chorób nerek). Wysoka ekspresja receptora dla naskórkowego czynnika wzrostu (EGFR) w nowotoworach obszaru głowy i szyi powoduje, że nie słabnie zainteresowanie leczeniem anty-EGRF. Ponieważ w trakcie leczenia dochodzi do powstania oporności, badane są możliwości sekwencyjnego zastosowania po cetuksymabie nowych leków z tej grupy. Wstępne wyniki badań sugerują korzyść kliniczną z takiego postępowania (abstr. 6001 — afatynib, abstr. 6002 - Sym004 - mieszaniana 2 przeciwciał IgG1 przeciwko EGFR).

Rokownicze znaczenie HPV u chorych na raka ustnej części gardła nie budzi obecnie wątpliwości. Ponad połowa (a według niektórych badaczy nawet do 90\%) chorych na raka ustnej części gardła jest zakażonych HPV, najczęściej typem 16. Są to chorzy młodsi, w lepszym stanie ogólnym, z mniejszym ubytkiem masy ciała, lepiej dbający o higienę jamy ustnej, niepalący lub palący mniej, niepijący lub pijący mniej, czy wreszcie swobodniejsi w sferze zwyczajów seksualnych w stosunku do pozostałej grupy chorych na raka ustnej części gardła. Być może wspomniane cechy epidemiologiczne lub odmienna biologia raka HPV-zależnego powodują, że chorzy ci mają lepsze rokowanie. W toczących się obecnie badaniach klinicznych podejmowane są próby stratyfikacji chorych pod względem zakażenia HPV lub wręcz konstruowane hipotezy badawcze skierowane do populacji chorych na raka HPV-zależnego. W jednym z zaprezentowanych badań podjęto próbę oceny, czy chorzy na raka ustnej części gardła z towarzyszącym zakażeniem HPV mogliby otrzymywać mniej agresywne i przez to mniej toksyczne leczenie (abstr. 6005). W grupie 90 chorych wykazano, że dawka 54 Gy pozwala uzyskać wysoki odsetek rocznych przeżyć wolnych od choroby (91\% w porównaniu z 89\% w grupie chorych napromienianych standardową dawką 69,3 Gy). Nie ma natomiast pewności co do roli zakażenia wirusem HPV u chorych na raki w innej niż ustna część gardła lokalizacji oraz u chorych z miejscowym lub uogólnionym nawrotem. Retrospektywne analizy materiału tkankowego wskazują, że również we wspomninanych populacjach może to być korzystny czynnik rokowniczy (abstr. 6006 i 6007).

\section{Rak płuca}

Rafał Dziadziuszko

Niedrobnokomórkowy rak płuca (NDRP) jest najczęściej rozpoznawany w III stopniu klinicznego zaawansowania, a większość chorych w tym stadium nie kwalifikuje się do leczenia operacyjnego. Standardem leczenia w tej grupie chorych jest kojarzenie metod miejscowych i systemowych i od kilku lat systematycznie prowadzone są badania oceniające różne schematy leczenia skojarzonego. Duże zaskoczenie wywołała prezentacja wyników badania RTOG 0617, w którym porównano przeżycia całkowite u chorych otrzymujących radioterapię w dawce standardowej $60 \mathrm{~Gy}$ i wyższej, wynoszącej 74 Gy, z równoczasową chemioterapią cetuksymabem lub bez cetuksymabu. W tym roku nie przedstawionono jeszcze oceny wpływu cetuksymabu, gdyż będzie to przedmiotem oddzielnej analizy. Niższa dawka napromieniania okazała się skuteczniejsza pod względem czasu przeżycia całkowitego oraz ocenionej radiologicznie kontroli miejscowej (ryzyko wznowy miejcowej było o 37\% wyższe u chorych leczonych dawką 74 Gy). Niewykluczone, że przyczyną tych niespodziewanych wyników jest połączenie kilku elementów, w tym błędne rozpoznanie progresji (oceny dokonywano w oparciu o klasyczną komputerowa tomografię, a zwiększone włóknienie miąższu płucnego po radioterapii 74 Gy mogło być interpretowane jako progresja), problemów w realizacji planu leczenia wysoką dawką, wydłużenia czasu leczenia i nasilenia repopulacji, nieodpowiedniego planowania i niskiej jakości leczenia (w badaniu włączono średnio 2 chorych na 1 ośrodek, napromienianie techniką IMRT stosowano w mniej niż połowie ośrodków, a nieakceptowalne odstępstwa od protokołu dotyczyły 20\% chorych leczonych dawkę $74 \mathrm{~Gy}$ ). Możliwe jest także, że część zgonów spowodowana była toksycznością leczenia (zwłaszcza powikłaniami płucnymi i kardiologicznymi).

W stopniu IIIA najwięcej kontrowersji budzą chorzy z cechą N2, u których korzyść z leczenia operacyjnego nadal nie jest jednoznacznie ustalona. Próby poprawy wyników leczenia obejmują w tej grupie kojarzenie zabiegu operacyjnego z radioterapią i leczeniem systemowym w różnych sekwencjach. W badaniu Szwajcarskiej Grupy Badawczej (SAKK), w którym dodano radioterapię do chemioterapii poprzedzajacej leczenie operacyjne, nie uzyskano wydłużenia czasu przeżycia wolnego od zdarzeń ani przeżycia całkowitego (abstr. 7503). Wydaje się, że jedna metoda miejscowa jest tak samo dobra jak skojarzenie dwóch metod i że obecnie przedoperacyjna radioterapia powinna być stosowana 
jedynie w ramach badań klinicznych i u chorych na raka szczytu płuca. W badaniu Nordyckiej Grupy Raka Płuca nie wykazano korzyści z dołączenia leczenia operacyjnego do chemioradioterapii w zakresie czasu przeżycia w całej grupie, ale uzyskano poprawę w podgrupie chorych w stopniu T1N2 i u chorych na raka gruczołowego (abstr. 7504).

Radioterapia stereotaktyczna zastosowana w leczeniu radykalnym u chorych na wczesnego NDRP pozwala uzyskać dobrą kontrolę miejscową (abstr. 7523). Jest to jednak postępowanie, które wymaga dużego doświadczenia nie tylko w przeprowadzeniu procedury, ale także przy kwalifikowaniu chorych, bowiem metoda ta powinna być zastosowana tyko u dobrze wyselekcjonowanych chorych. Odrębnym zagadnieniem są trudności diagnostyczne dotyczące nawrotów. W napromienianym obszarze dochodzi bowiem do znacznego uszkodzenia popromiennego tkanki płucnej, co stwarza znaczne problemy przy interpretacji obrazów komputerowej tomografii (abstr. 7520).

Przedstawiono również kilka badań z udziałem nowych leków u chorych na NDRP, m.in. szczepionki L-BLP25 (badanie III fazy START — abstr. 7500 — brak korzyści z leczenia podtrzymującego), ganetespidu (badanie II fazy GALAXY-1 - abstr. 8007 - inhibitor białka szoku termicznego 90 dodany do chemioterapii docetakselem wydłuża czas przeżycia wolnego od progresji i całkowitego), MPDL3280A (badanie I fazy - abstr. 8008 - przeciwciało skierowane przeciwko ligandowi dla receptora PD1 z obiecującą aktywnością), dabrafenibu (badanie Il fazy — abstr. 8009 — inhibitor kinazy BRAF wykazał akywność u chorych z mutacją aktywującą BRAF V600E).

Nie odnotowano żadnego postepu w leczeniu drobnokomórkowego raka płuca (DRP).

\section{Nowotwory OUN}

Monika Rucińska

Na tegorocznym Kongresie ASCO pojawiło się kilka prac dotyczących zastosowania bewacyzumabu w glejakach o wysokiej złośliwości. Ten najczęstszy guz mózgu u dorosłych charakteryzuje się wyjątkowo złym rokowaniem. Standardowym leczeniem pozostaje skojarzenie radioterapii z temozolomidem, jednak wyniki leczenia są złe. Nadekspresja naczyniowo-śródbłonkowego czynnika wzrostu oraz duża rola angiogenezy w rozwoju glejaków o wysokiej złośliwości powoduje, że od wielu lat w leczeniu tych nowotworów badana jest rola bewacyzumabu. Bewacyzumab w leczeniu glejaków został zarejestrowany w trybie przyspieszonej procedury, na podstawie zachęcających wyników badania II fazy. Lek jest szerzej stosowany w Stanach Zjednoczonych, w Europie rzadko. Przedstawiono pierwsze badania III fazy z losowym doborem chorych dotyczące tego wskazania - badanie AVAglio, oceniające wartość bewacyzumabu dodanego do radioterapii $z$ temozolomidem u chorych na nowo rozpoznanego glejaka wielopostaciowego (abstr. 2005) oraz badanie RTOG 0825, przedstawione podczas sesji plenarnej (abstr. 1), oceniające korzyść z dołączenia bewacyzumabu do radioterapii. W obu badaniach wykazano wydłużenie czasu wolnego od progresji pod wpływem zastosowania bewacyzumabu, nie zaobserwowano natomiast korzyści w zakresie czasu całkowitego przeżycia. Ocena całkowitego przeżycia jest jednak utrudniona, ponieważ w obu badaniach znaczna część chorych w ramieniu kontrolnym otrzymywała w przypadku niepowodzenia bewacyzumab (procedura cross-over). Jakość życia chorych leczonych bewacyzumabem budzi kontrowersje - w badaniu AVAglio wykazano, że była ona lepsza, w badaniu RTOG — gorsza (abstr. 2003). Ocena jakości życia jest szczególnie ważnym elementem badań w populacji chorych na glejaki wielopostaciowe, ponieważ choroba i stosowane leczenie operacyjne wywołują szereg objawów znacznie upośledzających funkcjonowanie chorego (dysfukcje motoryczne, objawy neurologiczne, zaburzenia poznawcze). Tym bardziej należy więc ostrożnie podchodzić do terapii, które mogą to funkcjonowanie dodatkowo pogarszać.

Dodanie temozolomidu do radioterapii w glejakach o niskiej złośliwości nie poprawia skuteczności leczenia wśród ogółu chorych (abstr. 2007). Jest to niejednorodna grupa kliniczna i być może korzyść dotyczy wyselekcjonowanych chorych. Warto np. podjąć analizę wartości temozolomidu zależnie od markerów molekularnych (np. metylacja MGMT, mutacja IDH1 czy kodelecja 1p/19q). Niezależnie od tego należy pamiętać, że glejaki o niskiej złośliwości charakteryzują się powolnym wzrostem i wielu chorych w chwili rozpoznania nie wymaga bezzwłocznej radioterapii.

\section{Nowotwory przewodu pokarmowego}

Marzena Wełnicka-Jaśkiewicz

Jednym z ciekawszych doniesień w sesjach na temat nowotworów przewodu pokarmowego było badanie z losowym doborem chorych dotyczące obserwacji po radykalnym leczeniu z powodu raka jelita grubego (st. I-III). W grupie 1200 chorych pochodzących z 39 brytyjskich ośrodków wykazano, że intensywna obserwacja pozwoliła na zwiększenie odsetka nawrotów wykrywanych w stadium operacyjnym, jednak nie miało to wpływu na czas przeżycia (abstr. 3500). Co ciekawe, odsetek wykrytych nawrotów był niezależny od wyjściowego stopnia zaawansowania. Wielokrotnie powtarzane badania komputerowej tomografii nie zwiększyły korzyści w porównaniu z pojedynczym badaniem połączonym z regularnie wykonywanym badaniem CEA, podniosły natomiast ryzyko wtórnych nowotworów.

W leczeniu raka jelita grubego w stadium uogólnienia standardem jest chemioterapia, ewentualnie kojarzona 
z lekami molekularnie ukierunkowanymi. W odniesieniu do I linii leczenia i wyników badań celowość dołączania przeciwciał do chemioterapii jest jednak przedmiotem dyskusji. Zaprezentowane w tym roku badania nie rozwiały tych wątpliwości. Być może lepszy dobór chorych w oparciu o markery molekularne wpłynie na poprawę efektów leczenia. Retrospektywna analiza materiału tkankowego od ponad 1000 chorych uczestniczących w badaniu PRIME (skojarzone leczenie I linii — chemioterapia FOLFOX i panitumumab) wykazała wydłużenie o 5 miesięcy mediany czasu całkowitego przeżycia w grupie chorych bez mutacji RAS (KRAS także poza kodonem 12. i 13. oraz NRAS) pod wpływem leczenia skojarzonego w porównaniu z wyłączną chemioterapią (abstr. 3511). Mutacja BRAF nie miała predykcyjnego znaczenia, ale stanowiła niekorzystny czynnik prognostyczny, niezależnie od zastosowanego leczenia. Leczenie podtrzymujące w raku jelita grubego jest nieustannie przedmiotem zainteresowania badaczy. Zastosowanie bewacyzumabu z kapecytabiną pozwala na znamienne wydłużenie czasu do progresji (badanie CAIRO, abstr. 3502), ale podtrzymujace leczenie bewacyzumabem w monoterapi po I linii leczenia nie przynosi korzyści (badanie SAKK 41/06). W żadnym w tych badań nie wykazano wydłużenia mediany czasu całkowitego przeżycia, nie oceniono również jakości życia, co wydaje się być poważną słabością w ocenie korzyści z przewlekłego i toksycznego leczenia. W komentarzu do tych badań podkreślono także znaczny koszt obu badanych sposobów leczenia podtrzymujacego (ponad 30 tys. dolarów na jednego leczonego chorego).

Standardem paliatywnego leczenia chorych na zaawansowanego raka gruczołowego żołądka i przełyku pozostaje chemioterapia z udziałem cisplatyny i 5-fluorouracylu, brak jednak ustalonego sposobu postępowania w przypadku niepowodzenia leczenia I linii. Docetaksel w monoterapii pozwala na wydłużenie mediany czasu przeżycia w porównaniu z aktywnym leczeniem objawowym (badanie III fazy z losowym doborem chorych COUGAR-02, abstr. 4023). Leczenie obarczone jest wprawdzie typową dla tego leku toksycznością, ale u chorych otrzymujących chemioterapię rzadziej występują krwawienia z przewodu pokarmowego i dolegliwości bólowe.

W leczeniu uogólnionego raka trzustki standardowym postępowaniem jest chemioterapia z udziałem gemcytabiny. Nieco lepsze wyniki można uzyskać przy użyciu chemioterapii wg schematu FOLFORINOX, leczenie to jest jednak obarczone znaczną toksycznością i, biorąc pod uwagę profil chorych, rzadko można je zastosować. Nab-paklitaksel dołączony do gemcytabiny znamiennie poprawia skuteczność leczenia w porównaniu z wyłączną gemcytabiną (wyższy odsetek odpowiedzi, dłuższa mediana czasu do progresji i czasu całkowitego przeżycia, abstr. 4005). Konieczne są jednak dalsze badania porównujące to leczenie ze schematem FOLFORINOX.

\section{Nowotwory ginekologiczne}

Radosław Mądry

W przedstawionym podczas plenarnej sesji badaniu III fazy z losowym doborem chorych porównano 2 rodzaje chemioterapii z udziałem paklitakselu - w skojarzeniu z cisplatyną lub topotekanem z bewacyzumabem lub bez bewacyzumabu (randomizacja do 4 ramion) u chorych na raka szyjki macicy w stadium uogólnienia lub nawrotu miejscowego, które wcześniej nie otrzymywały chemioterapii. Chemioterapia z topotekanem nie okazała się lepsza od chemioterapii z cisplatyną. Zastosowanie bewacyzumabu pozwoliło na znamienne wydłużenie czasu wolnego od progresji oraz, co istotniejsze, czasu całkowitego przeżycia (badanie GOG 240, abstr. 3). Bewacyzumab okazał się pierwszym molekularnie ukierunkowanym lekiem, który poprawił wskaźniki przeżycia w nowotworach ginekologicznych.

Rozpoznawanie raka jajnika w późnych stadiach oraz złe wyniki leczenia skłaniają do ciągłych poszukiwań skutecznej metody badań przesiewowych. Badania przesiewowe mogą mieć zastosowanie jedynie w odniesieniu do kobiet z grupy wysokiego ryzyka. Brytyjski program wczesnego wykrywania raka jajnika w takiej grupie oparty o oznaczenia Ca125 i badania przezpochwowej ultrasonografii nie zwiększa odsetka rozpoznań w stopniu I i ll nawet wówczas, gdy badania Ca125 wykonywane są co 4 miesiące (abstr. 5507). Profilaktyczna chirurgia pozostaje obecnie standardem u kobiet z wysokim ryzykiem raka jajnika lub jajowodu.

W leczeniu raka jajnika nadal najważniejszą rolę odgrywa chirurgia i jej doszczętność (a więc maksymalna cytoredukcja) podczas pierwszego zabiegu operacyjnego. W celu poprawy wyników leczenia, szczególnie w zaawansowanym stadium nowotworu, od wielu lat prowadzone są badania dotyczące wartości indukcyjnej chemioterapii. W brytyjskim badaniu III fazy - CHORUS - porównano indukcyjną chemioterapię (3 cykle chemioterapii - operacja - 3 cykle chemioterapii) z pierwotnym leczeniem operacyjnym i uzuzpełniającą chemioterapią (abstr. 5500). Parametry czasu przeżycia wolnego od progresji i całkowitego nie różniły się w obu ramionach, co jest zgodne $z$ badaniem EORTC z 2008 roku. Indukcyjna chemioterapia jest akceptowalną metodą leczenia, ale wydaje się, że powinna być stosowana jedynie u chorych z przeciwwskazaniami do rozległego zabiegu operacyjnego. Niezwykle istotna jest właściwa ocena zaawansowania przed zabiegiem, by móc przewidzieć jego doszczętność. Wydaje się, że obecnie najlepszą metodą jest wykonanie laparoskopii zwiadowczej — bardziej dokładnej niż badania obrazowe.

W leczeniu systemowym standardem pozostaje skojarzenie paklitakselu z pochodnymi platyny. Skuteczność tego leczenia w zaawansowanym nowotworze jest jednak niewielka, mediana czasu do progresji wynosi ok. 15-18 miesięcy, a średni czas przeżycia nie przekracza 3 lat. Zaprezen- 
towane dwa tegoroczne doniesienia to badania negatywne (abstr. 5501 — ocena cotygodniowych dawek karboplatyny, abstr. 5502 - ocena topotekanu i cisplatyny), a zatem w najbliższym czasie nie należy się spodziewać zmiany standardu.

Wartość systemowego leczenia w celu podtrzymania korzyści uzyskanej pod wpływem leczenia indukcyjnego w zaawansowanym raku jajnika budzi wątpliwości. Jak dotąd potwierdzono wartość podtrzymującego leczenia w odniesieniu do niektórych nowotworów układu krwiotwórczego (np. chłoniak grudkowy, szpiczak plazmocytowy), natomiast w szeregu guzów litych (np. raku piersi, raku jelita grubego, drobnokomórkowym raku płuca) wykazano, że postępowanie takie nie przynosi korzyści. Leczenie podtrzymujace $w$ raku jajnika teoretycznie jest uzasadnione wysokim odsetkiem odpowiedzi na leczenie I linii i bardzo częstą progresją w krótkim czasie. Przedstawione w tym roku dwa badania dotyczące tego zagadnienia (z pazopanibem — abstr. 5503 i olaparibem — abstr. 5505) wykazały wydłużenie mediany czasu do progresji pod wpływem leczenia podtrzymujacego, jednak bez wpływu na czas całkowitego przeżycia lub poprawę jego jakości.

\section{Czerniaki}

\section{Piotr Rutkowski}

Rosnąca zachorowalność na czerniaki skóry (podwojenie liczby zachorowań w ciągu ostatniej dekady) i agresywny przebieg choroby u znacznej części chorych stanowi istotne wyzwanie dla współczesnej onkologii. Korzyść z profilaktyki pierwotnej, polegającej na ograniczeniu ekspozycji na promieniowanie słoneczne jest dobrze udokumentowana, jednak jej realizacja pozostawia wiele do życzenia. W ostatnich latach obserwuje się natomiast znaczny postęp w zakresie leczenia systemowego, a to za sprawą rozwoju biologii molekularnej oraz immunoonkologii. Najważniejsze kierunki badań dotyczą nieswoistej immunoterapii oraz inhibitorów kinaz BRAF i MEK, które są głównymi punktami mutacji w czerniakach. Oprócz bezpieczeństwa zarejestrowanych już preparatów przedmiotem badań są kombinacje nowych leków. Zaktualizowane wyniki badań dla inhibitorów kinazy BRAF — wemurafenibu (abstr. 9046, lek dostępny w Polsce w ramach programu lekowego) i dabrafenibu (abstr. 9013) potwierdziły podobną skuteczność obu leków oraz profil najczęstszych zdarzeń niepożądanych — raka kolczystokomórkowego i rakowiaka kolczystoskomórkowego. Naturalną konsekwencją zastosowania inhibitorów kinazy BRAF jest reaktywacja zablokowanego lekiem szlaku kinazy MAP, skutkująca opornością na leczenie. Uzasadnia to próby kojarzenia inhibitorów BRAF oraz inhibitorów kolejnej kinazy tego szlaku - MEK. Ta podwójna blokada szlaku kinazy MAP — kombinacja dabrafenibu oraz trametynibu — może przezwyciężać pierwotną i opóźniać wtórną oporność na ha- mowanie szlaku BRAF u chorych na zaawansowane czerniaki z obecnością mutacji BRAF, przy czym wyniki są znacznie lepsze u chorych nieleczonych wcześniej inhibitorem kinazy BRAF (abstr. 9005). Niwolumab (przeciwciało monoklonalne ukierunkowane na receptor PD-1) to obiecujący lek, który ma korzystniejszy profil bezpieczeństwa i wyższy odsetek odpowiedzi niż leki anty-CTLA4 (abstr. 9006, badanie I fazy). Badania późniejszych faz oceniające niwolumab (zarówno w monoterapii, jak i w skojarzeniach) są w toku. Szczególnie obiecujące wydaje się być połączenie niwolumabu z ipilimumabem, które pozwala zablokować punkty kontrolne układu immunologicznego. Toczą się także badania leków ukierunkowanych na ligand dla receptora PD-1 - anty PD-L-1 (abstr. 9010). W większości są to badania wczesne i konieczna jest weryfikacja tych obiecujących wyników w badaniach III fazy, a także identyfikacja czynników predykcyjnych dla immunoterapii.

W leczeniu zaawansowanych postaci czerniaka gałki ocznej od lat nie obserwowano postępu. Selumetinib, inhibitor kinazy MEK1/2, w badaniu II fazy wykazał znamienną poprawę czasu wolnego od progresji w porównaniu z temozolomidem lub dakarbazyną (abstr. 9003).

\section{Mięsaki}

Piotr Rutkowski

Wykład dotyczacy mięsaków zdominowały prace związane z leczeniem GIST. Badanie EORTC potwierdziło wartość leczenia uzupełniającego imatynibem u chorych na GIST o dużym ryzyku nawrotu (abstr. 10500). W grupie 908 chorych 2-letnie leczenie pooperacyjne wpłynęło na wydłużenie czasu przeżycia wolnego od nawrotu oraz tendencję do poprawy przeżyć wolnych od niepowodzenia leczenia imatynibem. Chorzy otrzymujący uzupełniające leczenie w razie niepowodzenia otrzymywali imatynib dłużej niż chorzy bez tego leczenia. Stanowi to potwierdzenie wcześniejszej obserwacji, że uzupełniające leczenie nie powoduje wytworzenia wtórnej oporności na imatynib. Niestety, leczenie to nie jest jeszcze w Polsce dostępne. W leczeniu 1. linii uogólnionych postaci GIST standardem pozostaje także imatynib, bowiem nilotynib okazał się mniej skuteczny (abstr. 10501). Regorafenib jest obecnie zarejestrowany do 3. linii leczenia (po niepowodzeniu imatynibu i sunitynibu). Analizy molekularne materiału tkankowego z badania rejestracyjnego GRID wykazały, że obecność wtórnych mutacji KIT ma niekorzystne znaczenie rokownicze oraz wpływa na wyniki leczenia regorafenibem (abstr. 10503). Z uwagi na trudności w rozpoznawaniu wtórnych mutacji (przy wieloogniskowej progresji możliwe jest występowanie różnych mutacji w poszczególnych ogniskach) obiecującą metodą diagnostyki mutacji wydaje się być analiza DNA osocza metodą BEAMing. W przyszłości może to służyć opracowa- 
niu skuteczniejszych preparatów i pomóc w precyzyjnym doborze leczenia.

\section{Leczenie wspomagające}

Renata Zaucha

Przerzuty nowotworowe do kości występują u ok. 80\% chorych, a towarzyszące im objawy kliniczne (m.in. ból, patologiczne złamania, hiperkalcemia, zespół ucisku rdzenia) istotnie pogarszają jakość życia chorych. Paliatywna radioterapia u większości chorych zmniejsza nasilenie bólu, ale u części chorych dochodzi do nawrotu dolegliwości bólowych spowodowanych progresją w obszarach uprzednio napromienianych. W powtórnym napromienianiu stosuje się zwykle metodę frakcjonowania dawki. W prospektywnym badaniu z losowym doborem chorych przy powtórnej radioterapii bolesnych przerzutów kostnych wykazano podobną skuteczność (mierzoną odsetkiem obiektywnych odpowiedzi wg kwestionariuszy oceny bólu i zapotrzebowania na opioidy) pojedynczej frakcji 8 Gy lub 4 frakcji po 5 Gy (abstr. 9502). Tolerancja pojedynczej frakcji była lepsza, znamiennie rzadziej powodowała utratę apetytu, wymioty i biegunkę. Nie stwierdzono znamiennych różnic w liczbie złamań patologicznych oraz jakości życia. Pojedynczej frakcji należy raczej unikać u chorych z masywnymi zmianami w kręgosłupie z uwagi na większe (choć nieznamienne) ryzyko złamań i objawowego ucisku rdzenia kręgowego.

Alternatywną do radioterapii metodą miejscowego leczenia przerzutów do kości może być MRgFUS — zogniskowana fala ultradźwiękowa stosowana pod kontrolą rezonansu magnetycznego, która „podgrzewa” ogniska nowotworowe do 80 st. C. W wieloośrodkowym badaniu prospektywnym III fazy w grupie chorych, którzy wyczerpali możliwości radioterapii, wykazano poprawę w porównaniu z placebo w zakresie kontroli bólu, ilości stosowanych opioidów oraz jakości życia (abstr. 9500). MRgFUS jest metodą jeszcze mało znaną, wymaga dalszych badań pod kątem ewentualnego ryzyka uszkodzenia narządów sąsiednich (m.in. nerwów, skóry, jelit), wydaje się jednak skuteczna i bezpieczna, szczególnie u chorych z przewidywanym krótkim czasem przeżycia, którzy wyczerpali możliwości radioterapii.

Neurotoksyczność związana z chemioterapią jest częstym problemem klinicznym, szczególnie w dobie powszechngo stosowania kilku linii chemioterapii. Jest powodowana przez wiele leków, a jej etiopatogeneza jest bardzo złożona. Bywa częstym powodem zaprzestania leczenia m.in. pochodnymi platyny czy alkaloidów barwinka, a leczenie tego powikłania jest mało skuteczne. Popularna od kilku lat metoda zapobiegania, polegająca na stosowaniu dożylnych wlewów wapnia i magnezu, została poddano ocenie w prospektywnycm badaniu z losowym doborem u chorych na wczesnego raka jelita grubego otrzymujących pooperacyjną chemioterapię wg schematu FOLFOX (abstr. 3501). Stwierdzono brak korzyści z takiego postępowania w zapobieganiu zarówno neurotoksyczności skumulowanej, jak i ostrej, indukowanej oksaliplatyną. Tymczasem najważniejsze znaczenie w zapobieganiu ma odpowiednia kwalifikacja chorych do leczenia, z uwzględnieniem czynników ryzyka neuropatii, takich jak cukrzyca czy nadużywanie alkoholu, właściwe dobranie dawki leku i okresowe przerywanie leczenia (metoda „stop \& go").

Wpływ diety na przebieg choroby nowotworowej i wyniki leczenia pozostają przedmiotem badań od wielu lat. Przeciwnowotworowe działanie polifenoli wykazano wcześniej w badaniach na liniach komórkowych, zwierzętach oraz w niewielkich badaniach II fazy u ludzi. W tym roku zaprezentowano pierwsze podwójnie zaślepione, kontrolowane placebo badanie III fazy z losowym doborem chorych, w którym oceniono wartość suplemetacji diety polifenolami w postaci tabletkowanej w grupie chorych na wczesnego raka gruczołu krokowego (abstr. 5008). Wykazano znamienną poprawę (mierzoną medianą wzrostu PSA) w grupie otrzymującej suplement w porównaniu z placebo, przy dobrej tolerancji tabletek z polifenolami, co zachęca do dalszych badań.

\section{Nowotwory układu moczowego}

Piotr Potemski

Standardem leczenia chorych na zarodkowe nowotwory jądra pozostaje chemioterapia BEP. W grupie o niekorzystnym rokowaniu przeżycia 5-letnie są udziałem jedynie połowy chorych. Intensyfikacja leczenia nie poprawia parametrów przeżycia i związana jest z wyższą toksycznością. Przedstawione $\mathrm{w}$ tym roku badania oceniające wartość chemioterapii TIP (cisplatyna, ifosfamid, paklitaksel, badanie Il fazy, abstr. 4501) i złożonej intensywnej chemioterapii paklitaksel-BEP (abstr. 4500) nie przyniosły zmiany standardu. W tym ostatnim badaniu potwierdzono natomiast dodatkowo wartość rokowniczą wczesnej odpowiedzi biochemicznej. Chorzy, którzy uzyskali znaczny spadek stężenia markerów w ciągu pierwszych tygodni leczenia, mieli znamiennie lepsze rokowanie.

U chorych na nasieniaki w I stopniu klinicznego zaawansowania stosuje się wymiennie 3 metody postępowania pooperacyjnego: uzupełniająca radioterapia, uzupełniająca chemioterapia karboplatyną oraz aktywna obserwacja, która zdobywa stopniowo coraz więcej zwolenników. W kilku badaniach wykazano, że odstąpienie od leczenia uzupełniającego wiąże się wprawdzie z ok. 20-procentowym odsetkiem nawrotów, ale leczenie zastosowane w momencie nawrotu jest na tyle skuteczne, że uzyskuje się niemal 100\% przeżyć 5-letnich. W kohortowym badaniu duńskim 
poddano ocenie losy niemal 2 tys. chorych na nasieniaka jądra w I stopniu klinicznego zaawansowania, obserwowanych przez wiele lat i potwierdzono wyniki wcześniejszych badań - w całej grupie odsetek 15-letnich przeżyć swoistych dla choroby wyniósł 99,5\%, a całkowitych - 92,1\% (abstr. 4502). Wykazano dodatkowo, że naciekanie drobnych naczyń, wielkość guza przekraczająca 4 cm oraz wyjściowy poziom hCG > 200 IU/I były czynnikami ryzyka nawrotu. Aktywna obserwacja wydaje się być zatem preferowanym standardem w tej grupie chorych i pozwala uniknąć niepotrzebnego leczenia (napromienianiem lub karboplatyną) u ok. $80 \%$ chorych. Dzięki badaniom obrazowym większość nawrotów wykrywa się w ciągu pierwszych 2 lat po leczeniu operacyjnym. Podobne wyniki uzyskano w badaniu obserwacyjnym chorych na nienasieniaki w I stopniu klinicznego zaawansowania, w którym aktywna obserwacja po leczeniu operacyjnym okazała się skutecznym i bezpiecznym standardem postępowania, szczególnie w grupie bez naciekania naczyń (abstr. 4503).

Przedstawiono systematyczny przegląd i metaanalizę 21 badań klinicznych z losowym doborem chorych, oceniających wpływ chemioterapii przed- lub pooperacyjnej na czas całkowitego przeżycia chorych na raka pęcherza moczowego naciekającego błonę mięśniową (abstr. 4544). Wykazano, że zastosowanie zarówno przedoperacyjnej jaki uzupełniającej chemioterapii wpływa na zmniejszenie względnego ryzyka zgonu (odpowiednio o $11 \%$ i $25 \%$ ). Chemioterapia uzupełniająca nie jest jednak nadal postępowaniem standardowym, bowiem brak jest wiarygodnych badań III fazy, potwierdzających jej wartość. Może być ona jednak rozważana u chorych w zaawansowaniu pT3-pT4 lub N+.

Standardem leczenia chorych na uogólnionego, opornego na kastrację raka gruczołu krokowego pozostaje docetaksel. Próby poprawy wyników leczenia poprzez kojarzenie docetakselu z lekiem molekualrnie ukierunkowanym (m.in. lenalidomid, bewacyzumab, dasatinib) nie przeniosły, jak dotąd, efektu. Dołączenie afilberceptu, nowego inhibitora naczyniowo-śródbłonkowego czynnika wzrostu, także nie wpłynęło na poprawę czasu całkowitego przeżycia, wiązało się natomiast ze znacznie większą toksycznością (abstr. 5002).

\section{Rak piersi}

Aleksandra Łacko

Jednym z najbardziej komentowanych doniesień na tegorocznym Kongresie ASCO było przedstawione w sesji plenarnej badanie aTTom, w którym porównano wartość 5- i 10-letniego uzupełniającego leczenia tamoksyfenem (abstr. 5). Późne nawroty po pierwotnym radykalnym leczeniu raka piersi nie są rzadkością. Stanowią one istotny problem, zwłaszcza w raku hormonozależnym, gdzie krzywe przeżycia praktycznie nie osiągają plateau, a roczne ryzyko nawrotu wynosi nawet po kilkunastu latach 2-3\%. Wydłużone leczenie tamoksyfenem zmniejszyło o jedną trzecią umieralność z powodu raka piersi w czasie pierwszych 10 lat od rozpoznania oraz o połowę w późniejszych latach, a także zmniejszyło ryzyko nawrotu raka piersi. Pozostało ono bez wpływu na ogólne przeżycia, co prawdopodobnie było spowodowane zwiększoną liczbą zgonów z innych powodów w grupie poddanej wydłużonej hormonoterapii. W grupie otrzymującej tamoksyfen przez 10 lat stwierdzono również około dwukrotnie większe ryzyko zachorowania na raka trzonu macicy. Wyniki badania aTTom potwierdzają obserwacje z opublikowanego w tym roku badania ATLAS. Wyniki obu tych badań pozwalają na zastosowanie wydłużonej uzupełniającej hormonoterapii tamoksyfenem u wybranych chorych (zarówno przed-jak i pomenopauzalnych) po analizie czynników rokowniczych, takich jak ryzyka późnego nawrotu, oczekiwanego czasu życia oraz wnikliwej ocenie ryzyka powikłań.

$\mathrm{U}$ chorych na wczesnego raka piersi z cechą cNO elementem standardowego leczenia operacyjnego jest biopsja węzła wartowniczego. Największe prospektywne badanie III fazy oceniające wartość tej procedury w porównaniu z usunięciem pachowych węzłów chłonnych w grupie chorych bez zajęcia węzła wartowniczego (NSABP B-32) nie wykazało różnic pomiędzy oboma sposobami postępowania chirurgicznego w zakresie czasu przeżycia wolnego od choroby i całkowitego przeżycia, a także w odniesieniu do kontroli miejscowej. W tym roku zaprezentowano uaktualnione po 10 latach obserwacji wyniki, które potwierdziły wcześniejsze obserwacje (abstr. 1000). U chorych z przerzutem w wartowniczym węźle chłonnym wykonuje się pachową limfadenektomię. W badaniu EORTC - AMAROS wykazano, że napromienianie pachowych węzłów chłonnych u takich chorych jest równie skuteczne i powoduje znacznie mniej wczesnych i późnych powikłań (szczególnie obrzęku limfatycznego i ograniczenia ruchomości ramienia) niż leczenie chirurgiczne (abstr. 1001).

Indukcyjna chemioterapia skojarzona z leczeniem anty-HER2 pozwala u chorych na wczesnego raka piersi przeprowadzić leczenie oszczędzające w ok. 80\% przypadków (abstr. 501). Zastosowanie podwójnej blokady anty-HER2 (trastuzumab skojarzony z lapatinibem) pozwala uzyskać więcej (aczkolwiek nieznamiennie) patologicznych całkowitych remisji (pCR) w porównaniu z trastuzumabem, ale obarczone jest większą toksycznością (abstr. 500).

Potrójnie ujemny rak piersi jest chorobą zróżnicowaną pod względem przebiegu klinicznego oraz markerów molekularnych. Najaktywniejszym leczeniem jest chemioterapia oparta o antracykliny i taksoidy. U części chorych chemioterapia oparta o pochodne platyny wykazuje znaczną aktywność, problemem pozostaje natomiast właściwy dobór chorych do takiego leczenia. Uzyskanie PCR pod wpływem 
indukcyjnej chemioterapii jest korzystnym czynnikiem rokowniczym. W grupie 150 chorych poddanych indukcyjnej chemioterapii przeprowadzono analizę podtypów molekularnych oraz ich związku z patologiczną odpowiedzią (abstr. 1005). Najmniej patologicznych całkowitych remisji stwierdzono u chorych z podtypem bazalnym oraz podtypem $z$ receptorem androgenowym.

Wielogenowe profile mają za zadanie uzupełniać ocenę ryzyka nawrotu dokonaną na podstawie wskaźników patologiczno-klinicznych. Kolejne badania potwierdzają prognostyczną i predykcyjną wartość tych testów (abstr. 506 - test PAM50, abstr. 507 - test Oncotype), tymczasem jednak stopień zaawansowania jest podstawą wyboru sposobu uzupełniającego leczenia.

\section{Miscellanea}

Barbara Radecka

Przedmiotem ostatniego wykładu tegorocznego „Spotkania..." były głównie zagadnienia związane z obserwacją chorych po radykalnym leczeniu onkologicznym. Wiele danych wskazuje, że w czasie obserwacji po leczeniu wykonuje się zbyt dużo badań, również bardzo kosztownych i często o nieudowodnionej skuteczności. Celem obserwacji po leczeniu jest bowiem wczesne wykrycie nawrotu miejscowego lub drugiego nowotworu oraz ocena i leczenie powikłań, a nie wczesne wykrycie bezobjawowych przerzutów odległych, co nie poprawia skuteczności leczenia ani jakości życia chorych. Pomimo precyzyjnych wytycznych w codziennej praktyce stosowanie u chorych po radykalnym leczeniu raka piersi nowoczesnych badań obrazowych, szczególnie scyntygrafii kości oraz tomografii komputerowej klatki piersiowej, jest bardzo częste (abstr. 6628). W odniesieniu do niedrobnokomórkowego raka płuca nie opracowano dotychczas jednoznacznych zaleceń odnośnie obserwacji takich chorych po zakończeniu leczenia, jednak liczba badań obrazowych wykonywanych w tej populacji wzrasta, szczególnie w grupie chorych rasy białej i o wyższym statusie socjoekonomicznym (abstr. 6505).

Ponad połowa młodych chorych na wczesnego raka piersi, u których możliwe jest przeprowadzenie leczenia z zaoszczędzeniem gruczołu piersiowego, decyduje się jednak na radykalną amputację piersi. Jest to spowodowane wieloma czynnikami kliniczno-patologicznymi, np. nosicielstwem mutacji BRCA1/2, przerzutami do węzłów chłonnych czy obawą chorej o swoją przyszłość (abstr. 6507). Często chore wierzą, że amputacja pozwala uzyskać lepszą kontrolę choroby niż leczenie oszczędzające (abstr. 9571).

Wyniki badań klinicznych są w codziennej praktyce odnoszone do szerokiej grupy chorych, z których wielu nie spełniałoby kryteriów włączenia do badania. W populacyjnym badaniu kohortowym wykazano, że u chorych na raka jelita grubego w Ill stopniu klinicznego zaawansowania, którzy otrzymywali uzupełniającą chemioterapię, poza badaniami klinicznymi uzyskuje się znamiennie gorsze wyniki niż u chorych leczonych w ramach badań klinicznych, ale lepsze niż u chorych, którzy nie otrzymywali uzupełniającego leczenia (abstr. 6502).

Ta sesja zakończyła tegoroczne „Spotkanie po ASCO”. Wszystkie wykłady w wersji wirtualnej dostępne są na stronie www.poasco.pl. Kolejne, XIII spotkanie odbędzie się w dniach 27-28 czerwca 2014 r.

Dr n. med. Barbara Radecka

Opolskie Centrum Onkologii

ul. Katowicka 66a, 45-060 Opole

e-mail:brad@onkologia.opole.pl 